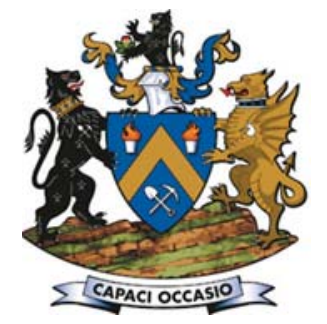

\title{
Evaluation of government equity participation in the minerals sector of Tanzania from 1996 to 2015
}

\author{
by P.R. Lobe ${ }^{1}$, A.S. Nhleko ${ }^{1}$, and H. Mtegha ${ }^{1}$
}

\section{Synopsis}

Government's equity role in the minerals sector is one of the nationalist measures implemented in order to ensure greater control and management of a country's mineral resources. This paper evaluates the Tanzanian government's equity participation in the minerals sector from 1996 to 2015. The research methodology included determination of the number of mineral rights, minimum allowable exploration expenditures in prospecting licences (PLS), and forms of equity role of the government. Data was collected and analysed for PLs, mining licences (MLS), and special mining licences (SMLs).

The study revealed a number of challenges faced by the Tanzanian government as regards its equity strategy in the mineral sector. One of the major challenges was the secrecy surrounding agreements and contracts entered into between the government and private sector investors, which were concluded via various business ownership and mineral development projects. This secrecy resulted in non-transparency and lack of accountability in the mining industry.

The financial benefits accruing to the government were inadequately realized, evident through inconsistent payments of corporate income tax and mining royalties by the mining companies. Furthermore, the government does not have solid mechanisms and frameworks for assessing non-financial benefits, thus it is difficult to measure the impact of these factors.

It is recommended that the Tanzanian government review the Mining Act and Regulations of 2010 to include the provision of solid mechanisms and frameworks for all forms of government equity role.

This paper is based on an MSc research study undertaken at the University of the Witwatersrand.

Keywords

Tanzania, minerals sector, government participation, equity role, joint venture.
It is important to note that the establishment of mines depends on the mineral resources being economically viable. Mines provide local citizens with secure employment and local content opportunities, raising their income and quality of life. Mineral exploitation is also a source of government revenue when mines produce or recover minerals resources through their value chains to the selling points.

Production and selling of mineral products enable government to collect revenue through royalties, corporate income taxes, and other legal means (Otto et al., 2006; Wise and Shtylla, 2007). Where there are good government policies, the minerals sector can integrate with other sectors of the economy to establish downstream industries (Highley, Chapman, and Bonel, 2004; Ministry of Energy and Minerals, 2009). Good government policies are defined as implementable plans or courses of action to influence and determine decisions, actions, and other matters in the interest of the country (Businessdictionary, 2017; Free Dictionary, 2017; Bendiola, 2013).

Since the inception of the Mining Act of 2010 and the Tanzanian government's mandate to the State Mining Corporation (STAMICO) to oversee government interests in prospecting, and medium- and large-scale mining, there has been no study to evaluate the equity role of the government in the minerals sector. A mining operation with a capital investment between US\$100 000 and US\$100 million or the equivalent amount in Tanzanian shillings is classified as a mediumscale operation. Large-scale mining operations are defined those where the capital investment is more than US\$100 million or its equivalent in Tanzanian shillings (Mining Act, 2010). This poses a question: 'How effectively has the

1 School of Mining Engineering, University of the Witwatersrand, South Africa.

(c) The Southern African Institute of Mining and Metallurgy, 2019. ISSN 2225-6253. Paper received Sep. 2018; revised paper received Mar. 2019. 


\section{Evaluation of government equity participation in the minerals sector of Tanzania}

equity role performance of the Tanzanian government in prospecting, and medium-and large-scale mining been since the enactment of Mining Act of 2010?' In order for this research study to make a meaningful contribution, the period from 1996 to 2015 was investigated.

\section{Tanzanian minerals endowment and mines}

This section discusses the nature, quality. and quantity of mineral resources and quantity of known mineral reserves. Tanzania's minerals endowment includes gold, tanzanite, diamonds, coal, uranium, iron ore, gemstones, and copper. These mineral deposits exist in stratigraphic formations such as Cenozoic volcanics, the Ubendian Belt, greenstone belts, and Archean cratons, to mention a few (Figure 1).

According to the Ministry of Energy and Minerals (2010), there are five groups of commodities that exist in Tanzania. These comprise:

> Metallic minerals such as gold, nickel, tin, rare earth elements, iron ore, copper, lead, and the platinum group metals (PGMs)

> Gemstones such as diamonds, tanzanite, ruby, emerald, and sapphire

> Industrial minerals such as phosphate, gypsum, limestone, kaolinite, graphite. and bauxite

> Building materials such as stone, sand, aggregates, gravel, and fireclay

> Energy minerals, including uranium and coal.

In Tanzania, information pertinent to geology and geophysics useful for assisting investors in selecting areas for prospecting is available from the Geological Survey of Tanzania (GST) Dodoma. Geological mapping has covered $90 \%$ of the country (Ministry of Energy and Minerals, 2015). According to the Ministry of Energy and Minerals (2015), mineral prospecting operations carried out between 1990 and 2015 have revealed reserves of approximately $2200 \mathrm{t}$ of gold and $5 \mathrm{Gt}$ of coal (see Figure 2a). Other mineral reserves are depicted in Figure 2b.
Tanzania plays a significant role in the global mining industry, supplying:

$>1.6 \%$ of the world's gold, making it the 15 th largest producer (Yager, 2013; Mineweb, 2015)

> 166500 carats of diamond in 2013/2014, making it 13th in the globe (US Geological Survey, 2015). This production was $0.23 \%$ of the annual total average production of 72.35 million carats

> Tanzanite - the only producer in the world (Ihucha, 2014; Yager, 2013).

a
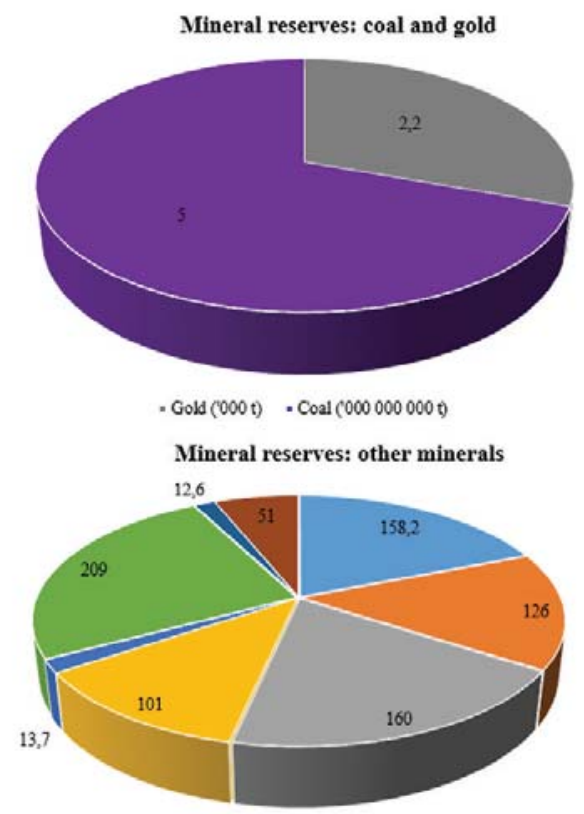

- Graphite $(000000 t) \quad$ - Iron ore $(000000 t)$
- Rare earth elements $(000000 t) \cdot$ Copper $(000000 t)$

- Tanzanite $(000000 \mathrm{t})$-Diamond (000 000 car)

- Uranium $(000000$ t) - Nidkel $(000000$ i)

Figure 2-Mineral reserves in Tanzania

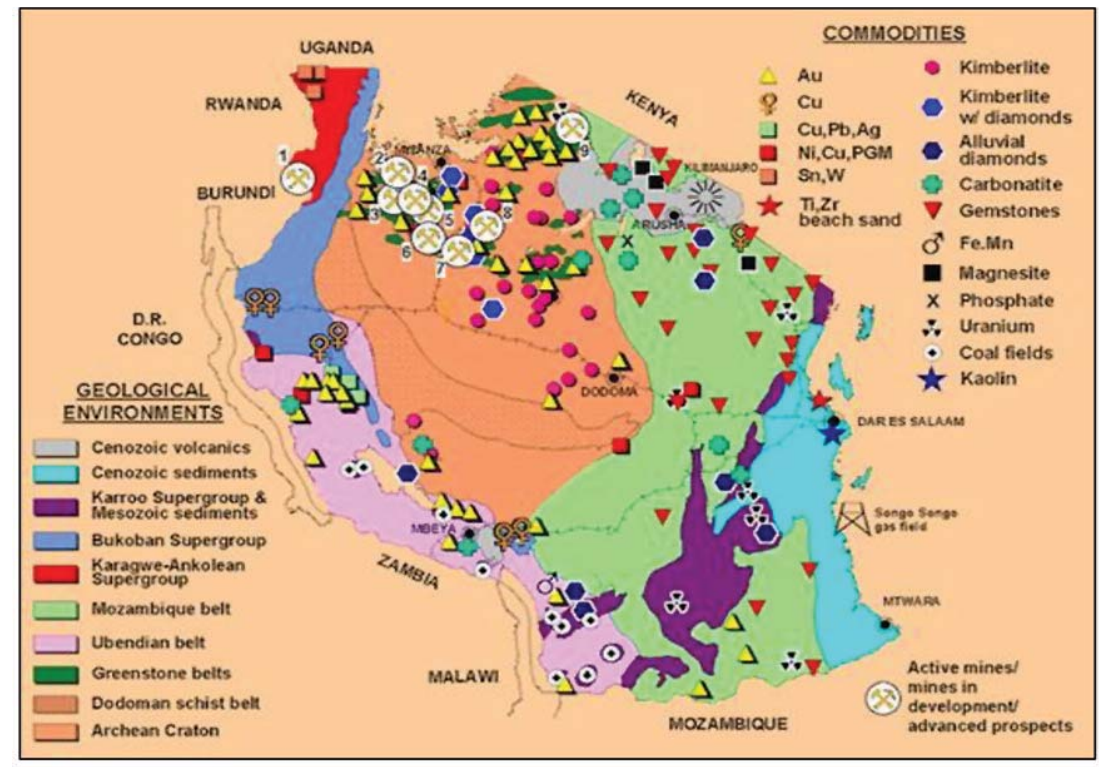

Figure 1-Geological terranes and selected mineral occurrences in Tanzania (Msabaha, 2006) 


\section{Evaluation of government equity participation in the minerals sector of Tanzania}

The tanzanite industry has not flourished in Tanzania despite its long history. This is due to the following reasons (Ihucha, 2014; Rimoch and Cherng, 2013; Dodgson, 2016):

> The continuing practice of exporting rough tanzanite

> Inadequate and inefficient jewellery cutting centres

- High rate of tanzanite smuggling

$>$ Tax evasion

> Lack of political will for implementing regulations in the tanzanite sector.

In Tanzania, from 1996 to 2015, there were nine active mines (Mwihava and Masanja, 2015; Tanzania Minerals Audit Agency, 2016a). These included six large-scale mines and three medium-scale mines (Table I).

\section{Evolution of the Tanzanian mineral sector}

\section{Equity role of government in the minerals sector before 1996}

In 1992, the Tanzanian government enacted the Public Corporations Act of 1992 to replace the Public Corporations Act of 1969 (Ministry of Finance and Planning, 1992). This action was due to the underperformance of parastatals during socialism and the self-reliance policy between 1967 and the late 1980s. Underperformance of parastatals was attributed to lack of local expertise, lack of managerial skills, embezzlement, bureaucracy, capacity underutilization, lossmaking, reliance on government subsidies, non-payment of taxes, overemployment and monopolistic behaviour of the operation, and huge debts (Muganda, 2004; Ngowi, 2009).

In 1993, the Tanzanian government established the Presidential Parastatal Sectoral Reform Commission (PSRC) to be in charge of privatization of state-owned organizations (Twaakyondo, Bhalalusesa, and Ndalichako, 2002; Muganda, 2004). Under the Public Corporations Act of 1992, all companies under government holding corporations were transferred to the Treasury Registrar (TR) for privatization through the PSRC. This action affected all companies under the State Mining Corporation (STAMICO), which were transferred to the TR and were kept under receivership or liquidated (Muganda, 2004; Ngonyani, 2014). Consequently, STAMICO was closed in April 1996.

\section{Specification and de-specification of STAMICO}

Specification of a public corporation means that the minister has declared closure of the corporation, while de-specification refers to the reversal of the order to close a public corporation. After the companies under government holding corporations had been placed in receivership or liquidated, STAMICO was listed in August 1997 as a specified public corporation under PSRC. This was after its closure in April 1996 (Ministry of Finance and Planning, 1992; Ngonyani 2014). As STAMICO became a specified public corporation, all its rights, privileges, powers, duties, or functions were vested in the board of directors. The board of directors then waited for STAMICO's shares to be allotted or sold by the government (Ministry of Finance and Planning, 1992). However, the government delayed the decision to allot or sell STAMICO, causing it to survive from 1996 until 2008. During this period, STAMICO concentrated on the provision of contract drilling services, consultancy work, property rental income, acquisition of mineral rights, and joint venturing (Ngonyani, 2014). Furthermore, during the same period, there were recommendations in 2008 from the Justice Mark Bomani Commission's Report favouring restoration of STAMICO rather than its closure. The government then decided to restore STAMICO (Bomani, 2008). De-specification of the corporation took place in April 2009 with the publishing of a de-specification order in the Government Gazette (State Mining Corporation, 2014).

\section{Changes in the Tanzanian minerals sector from 1996 to 2008}

In 1996, the government realized that the Mining Act of 1979 had failed to attract local and foreign mining investment. This, coupled with economic reforms undertaken by the government between the late 1980s and early 1990s, prompted the government to change the legislation (Tanzania Minerals Audit Agency, 2016b; Muganda, 2004; Ngowi, 2009; Weir, n.d.). The aim was to attract investors and bring into the country capital, technology, and expertise (Tanzania Minerals Audit Agency, 2016b). This resulted in the government endorsing the Minerals Policy of 1997 and Tanzania Mining Act of 1998 (State Mining Corporation, 2016; Ministry of Energy and Minerals, 2009). Other notable changes were the formulation of fiscal incentives aimed at attracting both local and foreign investors, and the opening of six large-scale mines as indicated in Table II.

This development brought about an increase in gold production from less than $1 \mathrm{t} / \mathrm{a}$ in 1998 to over $45 \mathrm{t} / \mathrm{a}$ in

Table I

Large and medium- scale mines in Tanzania as of December 2015

\begin{tabular}{|c|c|c|c|c|}
\hline Company/project & Scale & Product & District & Commissioning year \\
\hline $\begin{array}{l}\text { Merelani tanzanite mine (MTM) also known as TanzaniteOne tanzanite mine (TTM) } \\
\text { Ngaka coal mine (NCM) } \\
\text { New Luka gold mine (NLGM) } \\
\text { Bulyanhulu gold mine (BGM) } \\
\text { Buzwagi gold mine (BZGM) } \\
\text { Geita gold mine (GGM) } \\
\text { North Mara gold mine (NMGM) } \\
\text { Stamigold Biharamulo Mine (SBM) formerly known as Tulawaka Gold Mine (TGM) } \\
\text { Williamson diamonds mine (WDM) }\end{array}$ & $\begin{array}{l}\text { Medium } \\
\text { Medium } \\
\text { Medium } \\
\text { Large } \\
\text { Large } \\
\text { Large } \\
\text { Large } \\
\text { Large } \\
\text { Large }\end{array}$ & $\begin{array}{l}\text { Tanzanite } \\
\text { Coal } \\
\text { Gold } \\
\text { Gold } \\
\text { Gold } \\
\text { Gold } \\
\text { Gold } \\
\text { Gold } \\
\text { Diamond }\end{array}$ & $\begin{array}{l}\text { Simanjiro } \\
\text { Mbinga } \\
\text { Chunya } \\
\text { Kahama } \\
\text { Kahama } \\
\text { Geita } \\
\text { Tarime } \\
\text { Biharamulo } \\
\text { Kishapu }\end{array}$ & $\begin{array}{l}2001 \\
2012 \\
2012 \\
2001 \\
2009 \\
2000 \\
2002 \\
2005 \\
1940\end{array}$ \\
\hline
\end{tabular}




\section{Evaluation of government equity participation in the minerals sector of Tanzania}

\begin{tabular}{|c|c|c|}
\hline \multicolumn{3}{|c|}{$\begin{array}{l}\text { Table II } \\
\text { Mines established in Tanzania between } 1998 \text { and } \\
2003\end{array}$} \\
\hline Mine/project & $\begin{array}{c}\text { Year } \\
\text { commissioned }\end{array}$ & Status \\
\hline Golden Pride gold mine & 1998 & $\begin{array}{l}\text { Closed in } 2012 \text { after } \\
\text { reaching its end life. }\end{array}$ \\
\hline Geita gold mine (GGM) & 2000 & Still in operations \\
\hline Bulyanhulu gold mine (BGM) & 2001 & Still in operations \\
\hline North Mara gold mine (NMGM) & 2002 & Still in operations \\
\hline $\begin{array}{l}\text { Tulawaka gold mine (TGM) } \\
\text { currently known as Stamigold } \\
\text { Biharamuro Mine (SBM) }\end{array}$ & 2005 & Still in operation \\
\hline Buhemba gold mine & 2003 & $\begin{array}{l}\text { Closed in } 2007 \text { due } \\
\text { to undertaking of } \\
\text { uneconomical } \\
\text { large-scale mining }\end{array}$ \\
\hline
\end{tabular}

Sources: Tanzania Minerals Audit Agency (2016b); State Mining Corporation (2015b)

2010. Consequently, the minerals sector became the second largest in terms of foreign currency earnings (East African Community, 2011). Other outstanding developments stemming from of Minerals Policy of 1997 and Mining Act of 1998 from 1997 to 2008 were:

> Increased contribution of the mining sector to the GDP. from $1.4 \%$ in 1998 to $3.0 \%$ in 2008 (Muganyizi, 2012)

> Inflation-adjusted foreign direct investment (FDI) in the mineral sector through exploration and mining projects increased from US\$1.69 billion in 1997 to US $\$ 2.5$ billion in 2007 (Ministry of Energy and Minerals, 2009)

> Increased mineral exports value from US\$26 million in 1997 to US\$420 million in 2002, as indicated in Figure 3 (Msabaha, 2006).

Despite these achievements, Msabaha (2006) and the Ministry of Energy and Minerals (2009) highlighted major challenges as:

> Low level of integration of the minerals sector with other sectors of the economy
> Inadequate capacity to administer the sector

> Inadequate infrastructure such as roads, reliable power supply, and communications to support the sector

> Low level of value addition

- Growing negative public perception of the minerals sector. This is a result of the low contribution in both social and economic development.

Some of the impacts of these shortcomings included (Msabaha, 2006; Ministry of Energy and Minerals, 2009):

> Less contribution to the GDP by other sectors of economy, for example agriculture and manufacturing, due to their low level of integration with the minerals sector

- Low level of procurement of locally produced goods and services

> Increased transport costs from mines to the markets and from suppliers of goods and consumables to the mines.

\section{Changes in the Tanzanian minerals sector from 2009 \\ to 2015}

In order to address challenges that ensued under the Minerals Policy of 1997 regime, changes in the minerals sector were necessary (Msabaha, 2006). Accordingly, the government decided to review the minerals sector through the formulation of several committees in 2004. These committees included the Presidential Committee to advice the government on administering the minerals sector (Bomani, 2008; East African Community, 2011). This initiative resulted in the formulation of the Tanzania Mineral Policy of 2009 and Mining Act of 2010.

\section{Mineral rights owned by the Tanzanian government}

The analysis of all mineral rights owned by the government focused on prospecting licences (PLS), mining licences, (MLs) and special mining licences (SMLS) partially and wholly owned by STAMICO and NDC and TR. Figure 4 indicates that STAMICO has 17 partially owned and 20 wholly owned mineral rights from 1996 to 2015. STAMICO's partially owned mineral rights comprised 13 PLs, 2 MLs, and 2 SMLs while wholly owned rights included 19 PLs and 1 SML. The targeted minerals were gold, tanzanite, phosphate, rare earth elements (REEs), gypsum, kaolinite, feldspar, and coal.

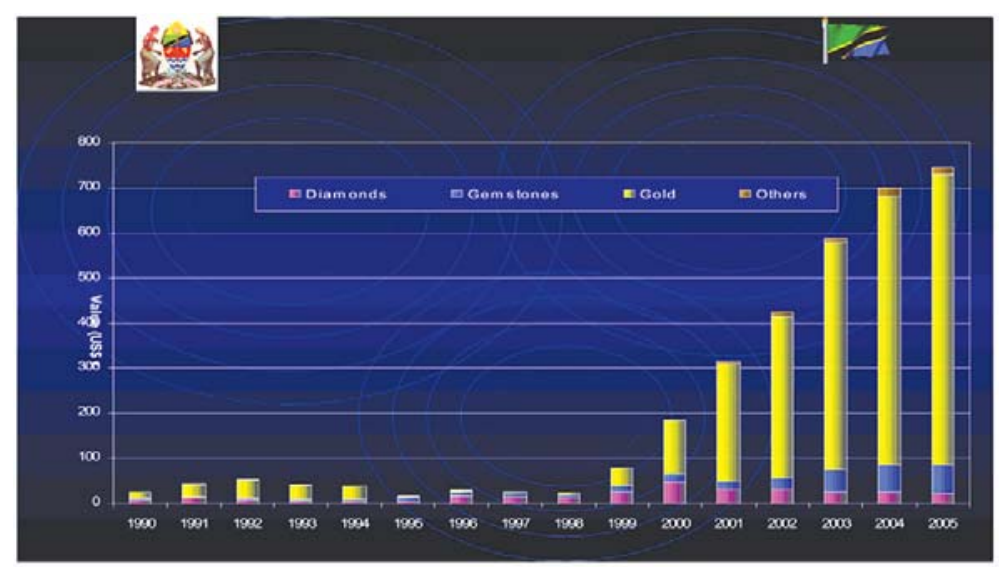

Figure 3-Tanzania's mineral exports from 1990 to 2005 (Msabaha, 2006) 


\section{Evaluation of government equity participation in the minerals sector of Tanzania}

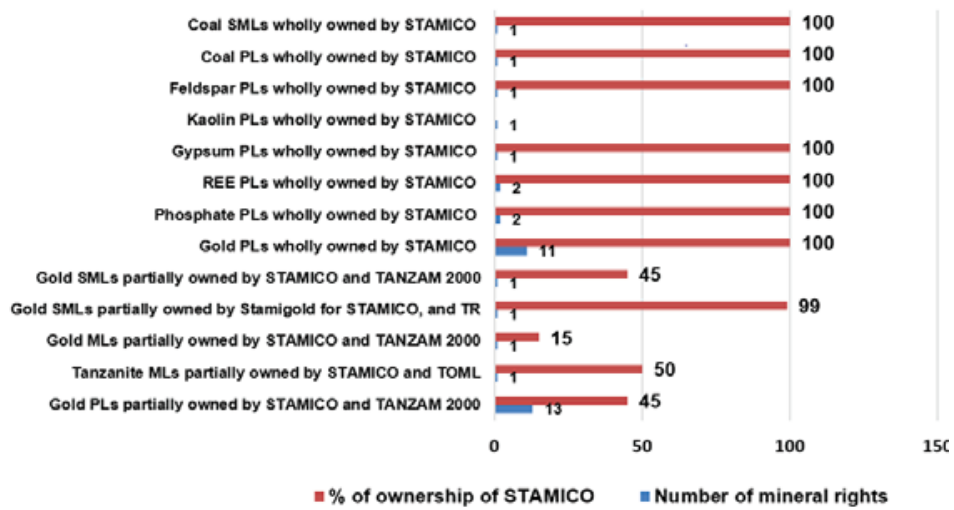

Figure 4-Mineral rights partially and wholly owned by STAMICO

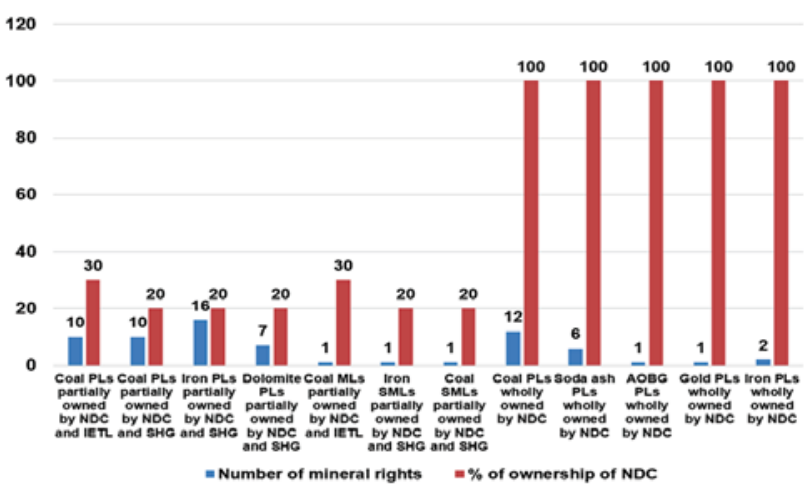

Figure 5-Mineral rights partially and wholly owned by NDC

Figure 5 shows that NDC had 46 partially owned and 33 wholly owned mineral rights from 1996 to 2015. The partially owned mineral rights consisted of 43 PLs, one ML, and two SMLs and wholly owned rights were 22 PLs. The targeted minerals included coal, iron ore, dolomite, soda ash, and all minerals other than building materials and gemstones (AOBG) and gold.

NDC played its role in the minerals industry by entering into joint ventures with Intra Energy Tanzania Limited (IETL) and Sichuan Hongda Group (SHG) of China through Tancoal Energy Limited (TEL) and Tanzania China International Mineral Resources Limited (TCIMRL), respectively. TEL was awarded 10 coal prospecting licences and one coal mining licence. In addition, TCIMRL acquired $10 \mathrm{coal}, 17$ iron ore, and 7 dolomite prospecting licences and one coal special mining licence (Figure 6).

TR partially owned one diamond SML, SML 216/2005. The TR's percentage of ownership of a mineral right vis-a-vis the private investor was $25 \%$. The private investor that owns the diamond SML with TR is Petra Diamonds Ltd, with a 75\% shareholding.

Under the government equity role from 1996 to 2015, coal was the most sought-after commodity, followed by gold and iron ore. This was presumably due to high granting of coal mineral rights by the Ministry of Energy and Minerals. From 1996 to 2015, the Ministry of Energy and Minerals granted 36 coal, 28 gold, and 19 iron ore mineral rights in line with the government equity role in the minerals industry.
Companies that owned mineral rights from 1996 in relation to the government equity role in the mining industry are presented in Figure 7. Each indicator in Figure 7 comprises the mineral type, type of mineral right, and percentage of ownership by the shareholder(s). It is deduced
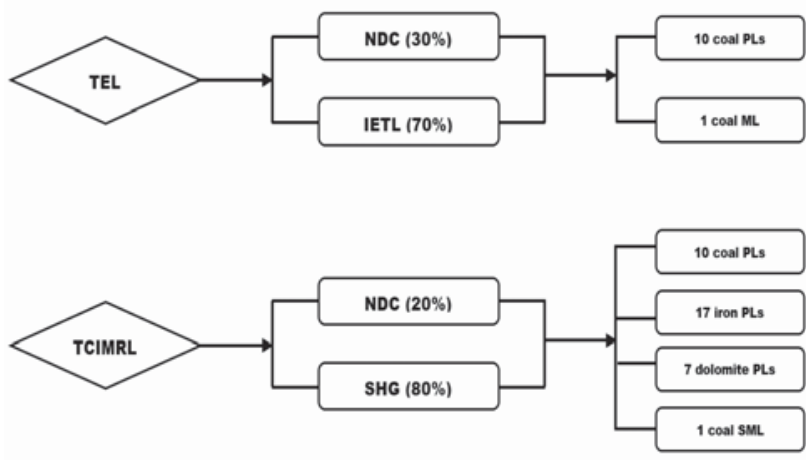

Figure 6-Shareholders of TEL and TCIMRL private joint venture (JV) companies and mineral rights

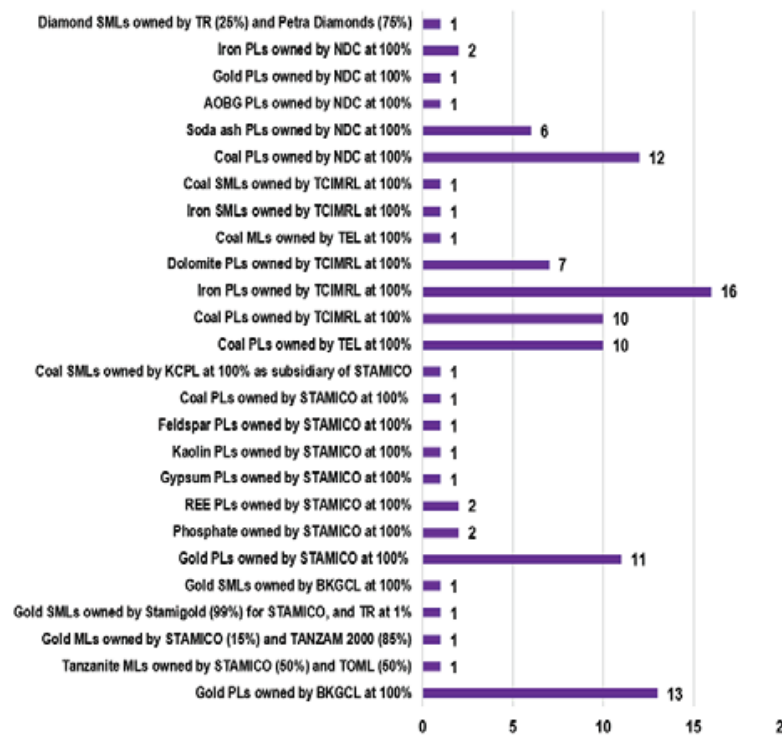

Figure 7-Mineral types, mineral rights, and business ownerships by government 


\section{Evaluation of government equity participation in the minerals sector of Tanzania}

that, out of 106 mineral rights, 60 were owned through joint ventures (JVs) between the state and private companies; 42 $(39.6 \%)$ were fully owned by STAMICO and NDC as sole commercial entities, and four (3.8\%) were owned through partnerships.

\section{Analysis of receivable annual levies for licences}

During the period under study the government received levies for licences issued under prospecting, mining, and special licence categories. Figure 8 presents annual levies payable by STAMICO, NDC, and TR to the government from 2011 to 2015 for holding licences issued by the government.

From Figure 8, the annual payable levies of STAMICO from 2011 to 2015 on its wholly and partially owned mineral rights exceeded those of NDC and TR. This was because STAMICO owned more MLs and SMLs than NDC and TR, with greater ownership shares. It should be emphasized here that the annual levy rates for MLs and SMLs, expressed in US dollars per square kilometre per annum, are much higher than for PLs, which caused higher payable annual levies on mineral rights under STAMICO to the tune of approximately US\$0.9 million.

Whereas STAMICO had more shares of ownership in mineral rights than $\mathrm{NDC}$ and $\mathrm{TR}$, a rationale that mostly necessitated its self-commitment in settling of annual levies, NDC was deemed to have relied on the private sector investors in settling the same. However, it seemed that the parastatal contribution of payable annual levies on partially and wholly government-owned PLs exceeded the private sector investors' contribution. This was attributed to many partially owned mineral rights issued to NDC having higher shareholding ownerships than private sector investors.

\section{Summary of the forms of the government equity role in the minerals sector}

There are four main types of government equity role, namely paid or full equity, carried equity, free equity, and free-carry equity. Paid equity is the equity capital financing or buying of shares in enterprises by government, as a private investor would do (Heller, 2011; Natural Resource Governance Institute, 2015; Cottarelli, 2012). Carried equity is when the private sector investor meets all capital costs and expenses in an investment without any financial contribution from government (Natural Resource Governance Institute, 2015; Cottarelli, 2012; McPherson, 2008). However, according to Heller (2011) and McPherson (2008), the recovery of an

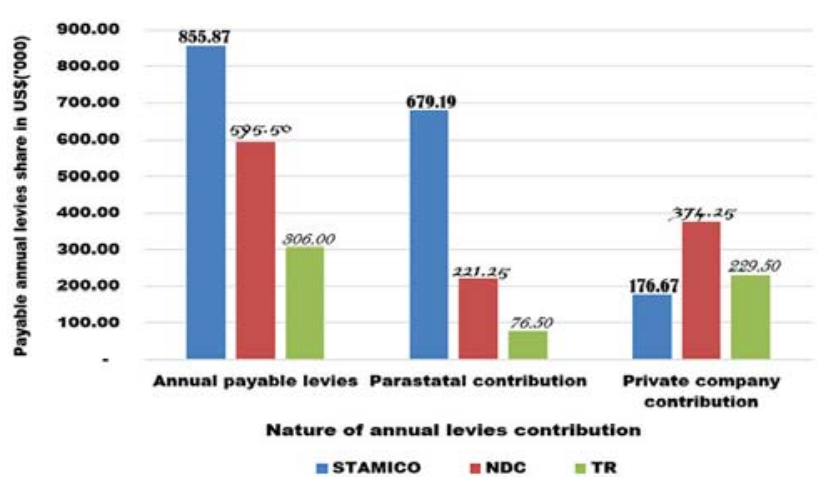

Figure 8-Payable annual levies for licences held from 2011-2015 investor's money spent as government contribution in an investment would be through government-foregone dividends with interest. Free equity is when the company grants a portion of its shares to the government at no cost (Heller, 2011; Cottarelli, 2012). Free-carry equity has the features of both free and carried equity (Kaba, 2017). It is when a percentage of mining company's shares is offered to the government by the company, and the company also carries the costs and expenses for the government. According to Kaba (2017), the government may contribute in kind by granting the mining licence and/or mining rights.

Although the Mining Act, 2010 defines free-carry equity in terms of the free-carried interest (FCI), this equity role approach is not yet practiced in Tanzania. In 2014, TZGT planned to execute free-carry equity in the Nachu graphite project (NGRP) and Mkuju River uranium project (MRUP). Negotiations for free-carried interest (FCI) for each project were conducted between the TZGT and project owners from 2014, but were concluded unsuccessfully in 2015 as the parties could not reach consensus on FCIs. This consequently impeded the signing of MDAs, which also limited execution of the free-carry equity role by the government. However, the government is negotiating with various stakeholders to implement free-carry equity. Table III summarizes the results for forms of government equity role in prospecting and medium- and large-scale mining. Most of the prospecting licence agreements were concluded under carried and paid equity types, comprising 56 and 41 PLs respectively. These agreements may lead to meaningful government participation in the mining industry since the government has paid in one way or another for the shares held in an entity. This participation will allow government to promote the mining industry as an invested party.

\section{Government equity role in prospecting}

Table IV depicts the financial benefits of the government equity role in 89 prospecting licences through STAMICO and NDC from 2011 to 2015. The total derived benefits amounted to US\$251839.60.

\section{Government equity role in medium-scale mining licences}

STAMICO and NDC are involved in carried equity in three medium-scale mines. The government did not earn any dividends from these mines during the period under review. STAMICO could not pay dividends as it was classified as a going concern and later reclassified; however, it was operating at a loss from 2013 to 2014 (Controller and Auditor General, 2015). NDC may not have paid an amount to the government because no dividends were declared for NDC based on the carried equity principle. It is expected that when STAMICO is profitable, dividends will be paid. Furthermore, once NDC has paid its debt of acquiring shareholding in full, dividends may be paid to the State provided that at least the mine is profitable.

\section{Government equity role in large-scale mining licences}

The government was involved in large-scale mining through exercising paid and carried equity roles. The paid equity role is through Stamigold Biharamulo mine and Kiwira coal mine, while carried equity is through Buckreef gold mine, 


\section{Evaluation of government equity participation in the minerals sector of Tanzania}

\begin{tabular}{|c|c|c|c|c|c|}
\hline \multirow[t]{2}{*}{ Area of participation } & \multirow{2}{*}{$\begin{array}{l}\text { Form of } \\
\text { equity role }\end{array}$} & \multicolumn{3}{|c|}{ Prospecting licences (PLs) and mining projects (mines) exercising respective forms of equity role } & \multirow[t]{2}{*}{ Total } \\
\hline & & STAMICO & NDC & TR & \\
\hline \multirow[t]{2}{*}{ Prospecting } & Carried & $13 \mathrm{PLs}$ & $43 \mathrm{PLs}$ & None & 56 PLs \\
\hline & Paid & 19 PLs & 22 PLs & None & $41 \mathrm{PLS}$ \\
\hline Medium scale mining & Carried & $\begin{array}{l}\text { Merelani } \\
\text { TanzaniteOne } \\
\text { Mining Ltd and } \\
\text { Kigosi gold mine }\end{array}$ & Ngaka Coal Mine & None & $\begin{array}{l}3 \text { medium } \\
\text { scale mines }\end{array}$ \\
\hline \multirow[t]{3}{*}{ Large-scale mining } & Carried & Buckreef gold mine & $\begin{array}{l}\text { Liganga Iron ore Mine and } \\
\text { Mchuchuma Coal Mine }\end{array}$ & $\begin{array}{l}\text { Williamson Diamonds } \\
\text { Mine }\end{array}$ & $\begin{array}{l}4 \text { large } \\
\text { scale mines }\end{array}$ \\
\hline & Paid & $\begin{array}{l}\text { Kiwira coal mine and } \\
\text { Stamigold Biharamulo mine }\end{array}$ & None & None & $\begin{array}{l}2 \text { large } \\
\text { scale mines }\end{array}$ \\
\hline & Free carry & \multicolumn{4}{|c|}{$\begin{array}{l}\text { Will apply in Nachu graphite project and Mkuju River uranium project pending meeting first of } \\
\text { agreeable FCls (through negotiations between government and projects owners) and signing of } \\
\text { Minerals development agreements. Negotiations deemed to continue after } 2015 \text {. }\end{array}$} \\
\hline
\end{tabular}

Table IV

Derivation of financial benefits of the government equity role in prospecting

\begin{tabular}{|l|l|c|}
\hline Payable annual levies retrieved & Category of financial benefit from 2011 to 2015 & Amount (US\$) \\
\hline \multirow{2}{*}{ STAMICO } & Payable annual levies from 13 PLs partially owned & 21941.70 \\
\cline { 2 - 3 } & Payable annual levies from 19 PLs wholly owned & 33504.30 \\
\hline NDC & Payable annual levies from 37 PLs partially owned & 89365.10 \\
\cline { 2 - 3 } & Payable annual levies from 20 PLs wholly owned & 107028.50 \\
\cline { 2 - 3 } & Total & $\mathbf{2 5 1 8 3 9 . 6 0}$ \\
\end{tabular}

Mchuchuma coal mine, Liganga iron ore mine, and Williamson diamond mine. The parastatals tasked with heading and protecting the role of government are STAMICO, NDC, and TR (the government agent). The government did not receive any earnings from these roles. This may be explained by the fact that some operations can only begin after certain infrastructure is in place, such as construction of Mchuchuma coal mine, the thermal power station, and a transmission line from Mchuchuma to Liganga.

\section{Summary of financial benefits to the government}

Table V summarizes the financial benefits to the government from 2006 to 2015. Based on the data collected and analysed in this paper, the financial benefits stood at US\$53.39 million against exploration costs of US\$2.06 million (for all PLS) and payable annual levies of US\$1.76 million (for all mineral rights) respectively. In the economics context, minimum allowable exploration expenditures and payable annual levies would be regarded as operating costs. These two costs may be incorporated in the income statements together with mineral sales revenues, cost of sales, other operating costs/expenses, depreciation expenses, etc. Then, the projects' net profits before and after taxes would be determined for payments of corporate income taxes to the government and dividends to the shareholders (Correia et al., 1993).

\section{Summary of non-financial benefits to the government} The government carried and paid equity roles in prospecting activities through STAMICO and NDC were analysed to assess the non-financial benefits they generated. Performances were analysed vis-a-vis three set of nonfinancial benefit indicators in prospecting, namely geoknowledge, government confidence in undertaking mining, and national capacity-building. Areas of non-financial benefits include greater control of the minerals sector, employment equity, human resource development, procurement, and enterprise development and community development (see Table VI).

There were two major challenges (shortcomings) faced by the Tanzanian government in prospecting, medium-, and large-scale mining. Firstly, STAMICO had financial constraints from 2013 to 2014 after it was reclassified from being a going concern. In this case, as highlighted by the Controller and Auditor General (2015), STAMICO had suffering a recurrence of losses, for instance losses of approximately US\$450 293 in 2013 and US\$632 452 in 2014. It is important that the government make interventions in STAMICO's operations with workable strategic solutions to prevent the parastatal from dwindling.

Lastly, the secrecy in agreements or contracts in partnerships, private JV companies, and mineral developments between the government and the private sector investors. Secrecy contributed to non-transparency and poor accountability in the prospecting, medium-, and large-scale mining projects under the government equity role. In addition, non-transparency and poor accountability in these 


\section{Evaluation of government equity participation in the minerals sector of Tanzania}

\begin{tabular}{|c|c|c|c|c|c|c|c|c|c|}
\hline \multirow[t]{2}{*}{ Mineral right } & \multicolumn{3}{|c|}{ Costs incurred in mineral rights } & \multicolumn{6}{|c|}{ Financial benefits from mineral rights } \\
\hline & $\begin{array}{c}\text { Minimum } \\
\text { allowable } \\
\text { exploration } \\
\text { expenditures } \\
\text { (US\$ million) }\end{array}$ & $\begin{array}{c}\text { Payable } \\
\text { annual } \\
\text { levies } \\
\text { (US\$ million) }\end{array}$ & $\begin{array}{c}\text { Total } \\
\text { costs } \\
\text { (US\$ million) }\end{array}$ & $\begin{array}{c}\text { Receivable } \\
\text { annual } \\
\text { levies } \\
\text { (US\$ million) }\end{array}$ & $\begin{array}{c}\text { Corporate } \\
\text { income } \\
\text { tax } \\
\text { (US\$ million) }\end{array}$ & $\begin{array}{c}\text { Mining } \\
\text { royalty } \\
\text { (US\$ million) }\end{array}$ & $\begin{array}{c}\text { Receivable } \\
\text { profits or } \\
\text { interests } \\
\text { (dividends) } \\
\text { through } \\
\text { benefits } \\
\text { roles }\end{array}$ & $\begin{array}{c}\text { Other } \\
\text { taxes } \\
\text { (US\$ million) }\end{array}$ & $\begin{array}{c}\text { Total } \\
\text { financial } \\
\text { benefits } \\
\text { (US\$ million) }\end{array}$ \\
\hline $\begin{array}{l}13 \text { PLs partially owned } \\
\text { by STAMICO }\end{array}$ & 0.22 & 0.02 & 0.24 & 0.02 & - & - & - & - & 0.02 \\
\hline $\begin{array}{l}19 \text { PLs wholly owned } \\
\text { by STAMICO }\end{array}$ & 0.23 & 0.03 & 0.26 & 0.03 & - & - & - & - & 0.03 \\
\hline $\begin{array}{l}37 \text { PLs partially owned } \\
\text { by NDC }\end{array}$ & 0.76 & 0.09 & 0.85 & 0.09 & - & - & - & - & 0.09 \\
\hline $\begin{array}{l}20 \text { PLs wholly owned } \\
\text { by NDC }\end{array}$ & 0.85 & 0.11 & 0.96 & 0.11 & - & - & - & - & 0.11 \\
\hline Subtotal US\$) & 2.06 & 0.25 & 2.31 & 0.25 & - & - & - & - & 0.25 \\
\hline $\begin{array}{l}\text { ML 490/2013 of Merelani } \\
\text { tanzanite mine (MTM) }\end{array}$ & - & 0.05 & 0.05 & 0.05 & 2.60 & 1.38 & - & 8.64 & 12.67 \\
\hline $\begin{array}{l}\text { ML } 496 / 2013 \text { of Kigosi } \\
\text { gold mine (KGM) }\end{array}$ & - & 0.06 & 0.06 & 0.06 & - & - & - & - & 0.06 \\
\hline $\begin{array}{l}\mathrm{ML} 439 / 2011 \text { of Ngaka } \\
\text { coal mine (NCM) }\end{array}$ & - & 0.12 & 0.12 & 0.12 & - & 1.11 & - & - & 1.23 \\
\hline Subtotal US\$) & - & 0.23 & 0.23 & 0.23 & 2.60 & 2.49 & - & 8.64 & 13.96 \\
\hline $\begin{array}{l}\text { SML 04/92 of Buckreef } \\
\text { gold mine (BKGM) }\end{array}$ & - & 0.16 & 0.16 & 0.16 & - & - & - & - & 0.16 \\
\hline $\begin{array}{l}\text { SML 533/2014 of Liganga } \\
\text { iron ore mine (LIOM) }\end{array}$ & - & 0.15 & 0.15 & 0.15 & - & - & - & - & 0.1 \\
\hline $\begin{array}{l}\text { SML 534/2014 of Mchuchuma } \\
\text { coal mine (MCM) }\end{array}$ & - & 0.13 & 0.13 & 0.13 & - & - & - & - & 0.13 \\
\hline $\begin{array}{l}\text { SML } 216 / 2005 \text { of Mwadui } \\
\text { diamond mine (WDM) }\end{array}$ & - & 0.31 & 0.31 & 0.31 & 0.11 & 9.44 & - & 25.92 & 35.78 \\
\hline $\begin{array}{l}\text { SML } 233 / 2005 \text { of Kiwira } \\
\text { coal mine (KCM) }\end{array}$ & - & 0.23 & 0.23 & 0.23 & - & - & - & - & 0.23 \\
\hline $\begin{array}{l}\text { SML 157/ } 2003 \text { of Stamigold } \\
\text { Biharamulo (SBM) }\end{array}$ & - & 0.30 & 0.30 & 0.30 & - & 0.82 & - & 1.61 & 2.73 \\
\hline Subtotal US\$) & - & 1.28 & 1.28 & 1.28 & 0.11 & 10.26 & - & 27.53 & 39.18 \\
\hline Total (US\$) & 2.06 & 1.76 & 3.82 & 1.76 & 2.71 & 12.75 & - & 36.17 & 53.39 \\
\hline
\end{tabular}

projects placed the Tanzanian government at risk of entering unfair and/or objectionable agreements or contracts.

The legislation states that public single (completely owned) or JV (partially owned) companies are required to release public certified copies of their annual financial statements to the Registrar of Companies (Correia et al., 1993; Marx et al., 1999). In addition, they are obliged to furnish their shareholders with mid-yearly interim reports and audited annual financial statements (Correia et al., 1993; Marx et al., 1999). These two requirements are a reflection of how transparent and accountable public single and JV companies are as compared to businesses such as sole commercial entities, partnerships, and private JV companies.

\section{Conclusions and recommendations}

The Tanzanian government's equity role from 1996 to 2015 in PLs, medium-, and large-scale mines involving carried and paid forms did not yield the expected outcomes because the government did not receive earnings. This was due to nontransparency and poor accountability in agreements in business ownerships that government and private sector investors pursued. In addition, sole commercial entities, partnerships, and private JV companies adopted in the government equity role are secretive in nature and this results in counter-productivity.

The Tanzanian government inadequately realized financial benefits through its equity role in prospecting, medium-, and large-scale mining. Inadequacy in financial benefits was characterized by inconsistent payments of corporate income tax, mining royalties, and other taxes by the mining companies. Another reason for this problem was the non-realization of profits and receipt of dividends from mining enterprises in which the government is sole commercial entity (via parastatals) or a shareholder with private-sector investors.

The Tanzanian government fairly realized non-financial benefits through its equity role in prospecting, medium-, and large-scale mining. Areas of non-financial benefits were greater control of the minerals sector, employment equity, human resource development, procurement, and enterprise 


\section{Evaluation of government equity participation in the minerals sector of Tanzania}

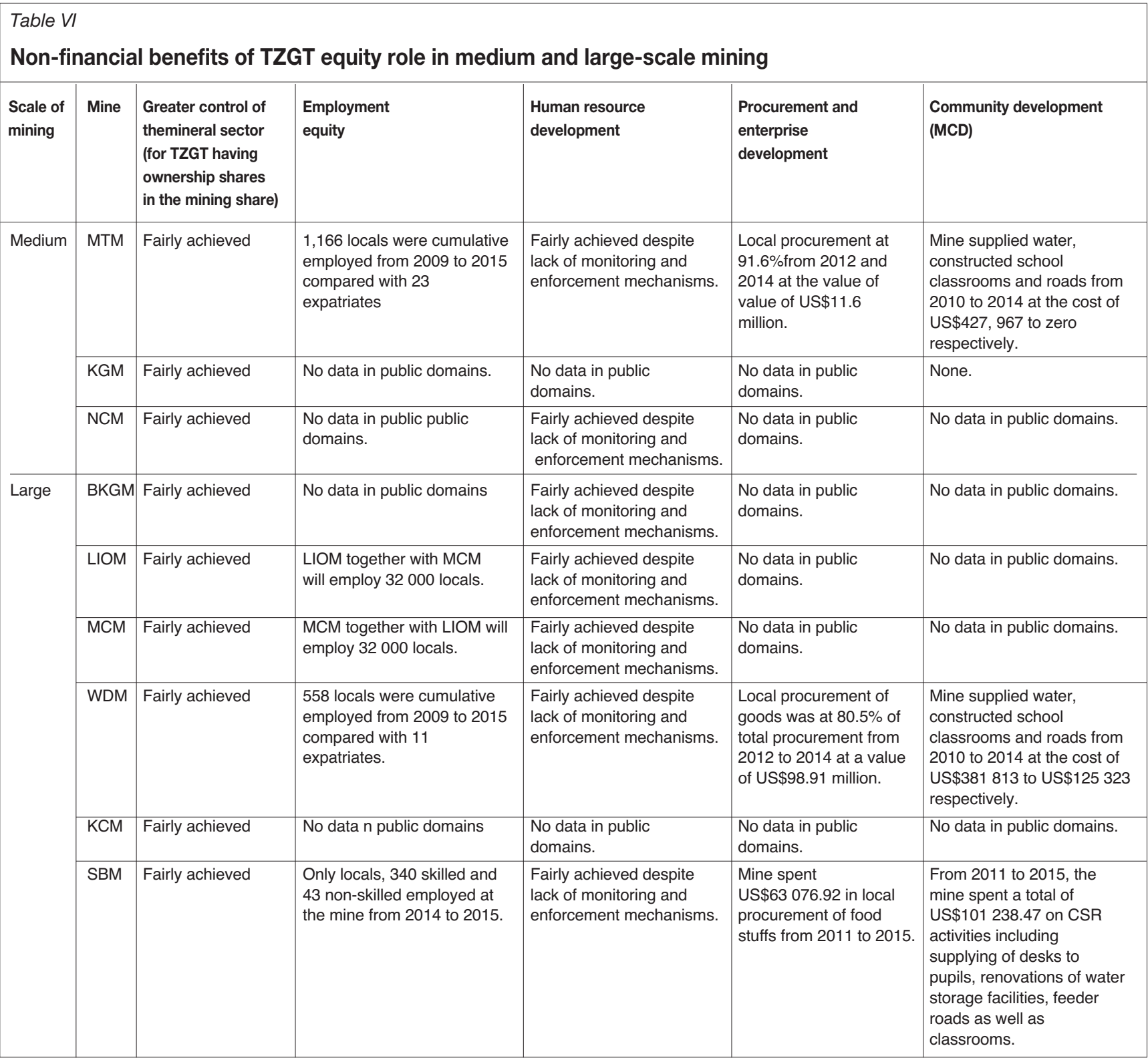

development as well as community development. However, in Tanzania there are no solid mechanisms and frameworks for overseeing of non-financial benefits.

It is recommended that the following issues be considered in order to improve the government's effective performance in the equity role strategy.

> Government to review the Mining Act of 2010 to include solid mechanisms and frameworks for all forms of government equity role, and assessing and measuring performance in equity role

- Government should develop oversight mechanisms to ensure that the effectiveness of its equity participation is monitored and its entities account to Parliament

> Government to review the Mining Act of 2010 and Regulations of 2010 to include frameworks for derivation, validation, and auditing of operating and capital costs used in mining projects where the State holds equity interest.

\section{References}

Bendiola, I. 2013. Characteristics of a good policy \& overall view of planning and its relationship to the management process.

https://www.slideshare.net/IvanBendiola/characteristics-of-a-good-policy [accessed 30 July 2017].

Bomani, M. 2008. Report of the Tanzanian presidential mining review committee to advise the government of the mining sector. http://www.policyforum-tz.org/sites/default/files/BomaniReportEnglish_0.pdf [accessed 2 February 2016].

Brown, M. 2013. Mining in Kenya - the start of new era? https://www.mayerbrown.com/files/uploads/Documents/PDFs/Mining_in_ Kenya2.pdf [accessed 9 September 2016]

BuSINESSDictionary 2017. Policy. http://www.businessdictionary.com/definition/policy.html [accessed 10 August 2017].

Controller and Auditor General. 2015. Report of the Controller and Auditor General on the financial statements of the state mining corporation for the six months period ended 30th June 2014. National Audit Office, Dar es Salaam, Tanzania. 


\section{Evaluation of government equity participation in the minerals sector of Tanzania}

Correia, C., Flynn, D., Uliana, E., and Wormald, M. 1993. Financial Management. Par Print, Cape Town, South Africa.

CotTARelLi, C. 2012. Fiscal regimes for extractive industries: Design and implementation. http://www.greenfiscalpolicy.org/wpcontent/uploads/2016/11/IMF-2012-Fiscal-Regimes-for-ExtractiveIndustries-Design-and-Implementation.pdf [accessed 5 December 2016].

Dodgson, L. 2016. Tanzanite: How Tanzania can profit from mining its rare stone. http://www.mining-technology.com/features/featuretanzanite-howtanzania-can-profit-from-mining-its-rare-stone-4698401/ [accessed 3 January 2017]

EAST African Community. 2011. Promotion of extractive and mineral processing industries in EAC- United Republic of Tanzania status. http://industrialization.eac.int/index.php?option=com_docman\&task=cat_ view\&gid=80\&Itemid=70 [accessed 9 February 2016].

FREEDICTIONARY 2017. Policy. https://www.thefreedictionary.com/ Government+policies [accessed 18 May 2017].

HELLER, P. 2011. National participation in oil and mining. http://www.eisourcebook.org/cms/August\%202013/National\%20Participa tion\%20in\%200il\%20\&\%20Mining.pdf [accessed 19 November 2016].

Highley, E.D., Chapman, R.G., and Bonel, A.K. 2004. The economic importance of minerals to the UK. https://www.bgs.ac.uk/downloads/ start.cfm?id=1301 [accessed 11 July 2016].

IHUCHA, A. 2014. How Kenya and India plunder tanzania's blue gem. https://empirevoice.blogspot.co.za/2014/12/how-kenya-and-indiaplunder-tanzanias.html [accessed 31 October 2016].

US Geological SuRvey. 2015. Mineral commodity summaries 2015. https://minerals.usgs.gov/minerals/pubs/mcs/2015/mcs2015.pdf [accessed 20 November 2016].

KABA, D. 2017. Free carried interests in Francophone Africa mining legislation Is there such a thing as a free lunch? http://www.fasken.com/en/freecarried-interests-in-francophone-africa-mining-legislation---is-theresuch-a-thing-as-a-free-lunch-01-26-2017/ [accessed 5 February 2017].

McPHeRson, C. 2008. State participation in the natural resource sector: Evolution, issues and outlook. http://www.imf.org/external/np/seminars/ eng/2008/taxnatural/pdf/mcpherson.pdf [accessed 17 February 2016].

Mineweb. 2015. Gold's Top 20 - Mines, miners and countries. http://www.mineweb.com/news/gold/golds-top-20-mines-miners-andcountries/, [Accessed 7 October 2016]

Mining Act. 2010. No. 14 Mining 2010. http://extwprlegs1.fao.org/docs/ pdf/tan97360.pdf [accessed 1 March 2019].

Ministry of Energy and Minerals. 2009. The Mineral Policy of Tanzania. https://mem.go.tz/wpcontent/uploads/2014/02/0014_11032013_Mineral_ Policy_of_Tanzania_2009.pdf. [accessed 29 March 2016].

Ministry of Energy AND Minerals. 2010. Mining Act, 2010. https://mem.go.tz/wp-content/uploads/2014/02/0013 11032013_Mining_Act_2010.pdf [accessed 7 April 2016].

MinisTRY of ENERGY AND MineRALS. 2015. Tanzania mining industry investor's guide.http://www.tanzania.go.tz/egov_uploads/documents/TANZANIA_M ining_Industry_Investor_Guide_-_June_2015_-1_sw.pdf [accessed 11 October 2016]

Ministry of Finance and Planning. 1992. The Public Corporations Act of 1992 http://faolex.fao.org/docs/pdf/tan142173.pdf. [accessed 16 June 2016].

MSABAHA, I.S. 2006. Tanzanian minerals sector- performance, fiscal benefits and challenges. World Bank Fiscal Issues Workshop, Washington DC, USA, October 2006. pp. 1-15. http://siteresources.worldbank.org/INTOGMC/Resources/3360991160575 823247/tanzaniaminister.ppt [accessed 31 January 2016].

MugandA, A. 2004 Tanzania's economic reforms - and lessons learned. http://www.tanzaniagateway.org/docs/tanzania_country_study_full_case. pdf [accessed 26 May 2016].
MuganyIZI, K.T. 2012. ICTD Research 1: Mining sector taxation in Tanzania. https://opendocs.ids.ac.uk/opendocs/bitstream/handle/123456789/2311/l CTD\%20Research\%20Report\%201_0.pdf?sequence=1\&isAllowed=y [accessed 13 December 2016].

MwiHAVA, C.X.N. and MasanjA, M. P. 2015. Annual Report July 2014 - June 2015.https://mem.go.tz/wp-content/uploads/2015/11/17.11.15annualreport-minerals-division.pdf [accessed 12 May 2016].

NATURAL Resource Governance InSTItUTe. 2015. State participation in oil, gas and mining. https://resourcegovernance.org/sites/default/ files/nrgi_StateParticipation_20150311.pdf [accessed 16 February 2016].

Natural Resource Governance Institute. 2015. State participation in oil, gas and mining. https://resourcegovernance.org/sites/default/ files/nrgi_StateParticipation_20150311.pdf [accessed 16 February 2016].

NGonyani, E.A. 2014. Strategic Plan 2014/15-2018/19. http://www.stamico.co.tz/wp-content/uploads/2014/12/STAMICO STRATEGIC-PLAN-201415-201819.pdf [accessed 9 June 2016].

NGowI, H.P. 2009. Economic development and change in Tanzania since independence: The political leadership factor. Proceedings of the Conference on Political and Managerial Leadership for Change and Development in Africa, Mbabane, Swaziland, September 2009. pp. 1-23. http://www.academicjournals.org/article/article1379789169_Ngowi.pdf [accessed 19 May 2016].

Otto, J., Andrews, C., Carwood, F., Doggett, M., Gu, P., Stermole, F., Stermole, J., AND TilTon, J. 2006. Mining royalties: A global study of their impact on investors, government, and civil society. http://siteresources.worldbank.org/INTOGMC/Resources/3360991156955107170/miningroyaltiespublication.pdf [accessed 28 September 2016].

Отто, J.M. Not dated. Mineral policy, legislation and regulation. https://commdev.org/userfiles/files/1217_file_UNCTAD_Otto.pdf [accessed 2 April 2016].

Rimoch, D. AND CheRnG, S. 2013. A rare and beautiful stone fails to shine: Tanzania's missed opportunity. http://knowledge.wharton.upenn.edu/article/rare-beautiful-stone-failsshine-tanzanias-missed-opportunity/ [accessed 12 November 2016].

State Mining Corporation. 2014. State Mining Corporation. http://www.stamico.co.tz/wp-content/uploads/2014/09/CORPORATEPROFILE1.pdf [accessed 18 June 2016].

State Mining Corporation. 2016. Corporate profile. http://www.stamico.co.tz/corporate-profile/ [accessed 25 December 2016].

TAnZAnia Minerals Audit Agency. 2016a. Annual Report 2015. http://www.tmaa.go.tz/uploads/TMAA_Annual_Report_2015-4.pdf [accessed 13 June 2016].

Tanzania Minerals Audit Agency. 2016b. History of the Agency. http://www.tmaa.go.tz/tmaa/about/category/history [accessed 29 July 2016]

TwaAkyondo, M.H., BhalaluSESA, P.E., and NdalichaKo, L.J. 2002. Factors shaping successful public private investorship in the ICT sector in developing countries the case of Tanzania. http://tanzaniagateway.org/docs/ICT_sector_in_developing_countries_the case_of_Tanzania.pdf [accessed 11 June 2016].

WEIR, A. Not dated. Development in post-independence Tanzania. http://www.fastonline.org/CD3WD_40/HDLHTML/EDUCRES/DEP18E/EN/ CH04.HTM [accessed 15 June 2016].

Wise, H. AND ShtylLa, S. 2007. The role of the extractive sector in expanding economic opportunity. https://www.hks.harvard.edu/mrcbg/CSRI/publications/report_18_EO\%20Extractives\%20Final.pdf [accessed 8 October 2016].

YAGER, R.T. 2013. The mineral industry of Tanzania. https://minerals.usgs.gov/minerals/pubs/country/2013/myb3-2013-tz.pdf [accessed 12 October 2016]. 